\title{
RFD
}

\section{A VOZ DO POVO É A VOZ DE DEUS? O MITO DO VALOR AXIOLÓGICO}

DA DEMOCRACIA

\author{
IS THE VOICE OF PEOPLE THE VOICE OF GOD? THE MYTH OF THE
}

AXIOLOGIC VALUE OF DEMOCRACY

\author{
Guilherme Dourado Aragão Sá Araujo ${ }^{1}$
}

Resumo: Tomando por contexto a discussão acerca da legitimidade do parlamento nas democracias contemporâneas, o presente artigo propõe-se a analisar a questão sob perspectiva dos limites do poder decisório da maioria democrática e da necessária discussão acerca do suposto valor axiológico do procedimento majoritário. Demonstra-se o surgimento da democracia direta na Grécia antiga e as implicações modernas que levaram ao desenvolvimento das formas representativas, bem como seus problemas inerentes. Utilizando-se de pesquisa bibliográfica, o ensaio expõe que os mecanismos propostos para verificação da legitimidade material, nas democracias, não se mostraram suficientes para afastar a possibilidade de abusos cometidos pelos grupos sociais majoritários. Conclui-se que esses problemas provocam a necessidade de se repensar o objeto deliberativo da democracia, de modo a, senão sanar, pelo menos reduzir ao máximo possível o perigo dos abusos da maioria.

Palavras-chave: teoria da democracia, autoridade da maioria, legitimidade, totalitarismo.

Abstract: Taking as context of the debate about the legitimacy of parliament in contemporary democracies, the present article proposes to analyze the issue from the perspective of the limits of decision-making power of democratic majority and the necessary discussion about the supposed axiological value of the majority procedure. It demonstrates the emergence of direct democracy in ancient Greece and the modern implications that led to the development of representative forms, as well as their inherent problems. Through literature research, this essay exposes that the proposed mechanisms for verifying material legitimacy in democracies have not been proven sufficient to avoid the possibility of abuses committed by the majority social groups. It is concluded that these problems provoke the need to rethink the deliberative object of democracy, in order to, if not solve, at least reduce as much as possible the danger of abuses of the majority.

Keywords: theory of democracy, authority of the majority, legitimacy, totalitarianism.

\footnotetext{
${ }^{1}$ Advogado. Mestre em Direito Constitucional pela Universidade de Fortaleza - Unifor. Professor de Direito do Centro Universitário Católica de Quixadá - Unicatólica.
}

Artigo recebido em 06/01/2016 e aprovado para publicação em 06/02/2018 
Democracia, ao lado do constitucionalismo, da separação dos poderes e dos direitos fundamentais, é uma forma de limitação do exercício arbitrário do poder político. Embora a democracia, em sua forma clássica grega, tenha surgido séculos antes das demais formas de limitação, sua concepção contemporânea está firmemente vinculada aos direitos fundamentais.

Em verdade, no conceito de Estado democrático de Direito, a democracia é tida como uma espécie de direito fundamental à parte, motivo pelo qual alguns doutrinadores apontam que o termo mais preciso seria meramente "Estado de Direito", corrigindo o suposto eufemismo.

É possível conceituar democracia como uma limitação ao exercício do poder político que consiste na participação direta ou indireta das vontades individuais do povo na formação daquela vontade geral do Estado por meio do princípio majoritário. Em sua forma direta, típica da Grécia clássica, os cidadãos diretamente decidiriam sobre os assuntos da cidade, enquanto, em sua forma indireta, os cidadãos elegeriam representantes para que estes decidissem sobre os assuntos em nome daqueles. Nas democracias contemporâneas, o voto nos representantes é a principal forma de exteriorização dessa manifestação da vontade popular, embora não seja a única.

Este conceito funcional é suficiente para demonstrar o aspecto formal da manifestação da vontade popular, mas não traz nenhuma menção ao seu aspecto material. Neste sentido, é possível realizar uma análise mais profunda quanto à legitimação popular que é conferida aos delegados do povo no exercício do poder.

Ora, uma coisa é o sistema político instigar que o povo lhe confira legitimidade por meio da manifestação de sua vontade. Outra coisa é averiguar até que ponto esta manifestação de vontade coincide com a vontade real do povo, e até que ponto a vontade manifestada pelo povo coincide com a vontade dos seus delegados. Para a presente obra, fez-se necessário um breve exame quanto ao espelhamento desta vontade popular na vontade dos delegados.

A definição de democracia nesse aspecto material não encontra consenso doutrinário. Isso porque existem outras nuances que envolvem o conceito de democracia 


\section{RFD}

além do mero respeito às formalidades apresentadas - trata-se da questão da legitimidade democrática.

Diante desse contexto, o presente artigo trata da análise dos limites do poder decisório dos grupos majoritários em um regime democrático, ao que se verifica a possibilidade de ocorrência de abusos cometidos pela maioria contra os grupos minoritários. Examinar até que ponto se pode admitir a influência decisória da maioria mostra-se fundamental à defesa dos direitos e garantias fundamentais dos grupos sociais minoritários que, de outro modo, poderiam estar sujeitos a agressões jurídica e politicamente justificadas pelo princípio majoritário da democracia.

\section{HISTÓRIA DO PENSAMENTO DEMOCRÁTICO: ENTRE ATOMISMO E HOLISMO FILOSÓFICOS}

Foi por volta do século $\mathrm{V}$ a.C. que surgiu, primeiramente em Atenas e depois em diversas outras cidades gregas, o que se convencionou denominar "democracia clássica". As primeiras experiências democráticas da história foram, em certa medida, consequência direta da superação da filosofia pré-socrática - estudo da natureza e da física - pelo estudo do homem e do corpo social que aquele, organicamente, constrói.

A democracia, ao contrário do que se pode supor, não surgiu por meio de imposição hierárquica, mas por meio de graduais e sucessivas reformas políticas instituídas, principalmente, pelo filósofo Sólon e pelo estratego Péricles. Não foi um sistema primeiramente idealizado e posteriormente posto em prática. A democracia não foi racionalmente pensada, mas vivenciada, pois surgiu de forma quase espontânea quando os homens gozaram de liberdade suficiente para tanto (GOYARD-FABRE, 2003).

Por não ter sido propriamente racionalizada antes de sua implantação, a democracia grega carece de um eixo filosófico principal, a exemplo do que se pode verificar no socialismo-comunismo, com a obra de Karl Marx ou no federalismo, com a obra de Alexander Hamilton, James Madison e John Jay, por exemplo (HELD, 2006).

Embora a democracia não tenha surgido por meio de um nodal próprio, é possível identificar, na filosofia grega, elementos que demonstram a evolução do pensamento político até culminar no desejo de uma forma de governo protagonizada pelo povo. Nesse aspecto, a obra de Demócrito de Abdera, embora somente tenha sobrevivido até a 


\section{RFD}

atualidade por meio de fragmentos, de certa forma apresenta interessantes fundamentos da essência do regime democrático.

O valor da democracia como regime político foi identificado pelo filósofo Demócrito de Abdera, que o explicou com base em sua doutrina atomista. Para essa teoria, o átomo é tido como a unidade fundamental que formava todas as coisas. É indivisível, invisível, infinito em quantidade, pleno, uno, eterno e imutável. Tudo era formado por átomos (ALBUQUERQUE; ARAUJO, 2017).

Essas unidades, segundo a doutrina atomista de Leucipo e, principalmente, de seu discípulo Demócrito, seriam os elementos primordiais de tudo o que existe. Como unidades indivisíveis de matéria, os átomos divergiam entre si pela forma geométrica e pelo peso. Átomos arredondados seriam responsáveis pela percepção do sabor adocicado, enquanto átomos com ângulos agudos seriam responsáveis pelo sabor amargo, por exemplo. A percepção gustativa de um sabor ou de outro era percebida com base no princípio majoritário: no sabor doce havia mais átomos arredondados que agudos, por exemplo (CHAUÍ, 2010).

Os átomos possuíam movimento e interagiam entre si ao se chocarem ou se afastarem. Podiam unir-se conforme o encaixe de suas formas geométricas, e, uma vez unidos, formavam um turbilhão que atrairia outros átomos, algo que demonstra um entendimento incipiente da gravidade. Ao crescerem em tamanho, esses agrupamentos de átomos tornar-se-iam visíveis e, assim, originariam todas as coisas.

$\mathrm{O}$ atributo de indivisibilidade revela que, para os atomistas, o átomo era a unidade da matéria. Nada existia que não fosse um composto de átomos, invisíveis, de tão pequenos. Eram infinitos em número, plenos, unos, eternos e imutáveis. Em outras palavras, os átomos eram absolutos em si, e não dependiam de nada mais para existir. Gozavam de asseidade, ou seja, existiam por sua própria potência.

Antes dos atomistas, outros filósofos já haviam teorizado sobre o desvelo do elemento primordial da matéria. A inovação da escola atomista de Abdera foi a suposição de que sua arché não ocupava todo o espaço físico. Por uma questão lógica, uma vez que se afirmara que os átomos possuíam movimento e se agrupavam para criar as coisas que existem, perceberam deveria haver um vazio por onde os átomos poderiam se mover. Com esse vazio, haveria espaço não corpóreo, não ocupado por matéria. 


\section{RFD}

Para os atomistas, a physis era o átomo e o vazio. Percebe-se um fundamento binário nessa doutrina: de um lado, haviam os átomos (a matéria), enquanto, do outro, havia o vazio (a ausência de matéria). Átomos e vazio, vida e morte, positivo e negativo, ligado e desligado. Um dependia do outro pois, se não houvesse vazio, os átomos não poderiam se mover e não poderiam se agrupar para formar as coisas. Atualmente, utiliza-se esse mesmo sistema binário para movimentação de informações, sobretudo na ciência da informática. Demócrito propôs o mesmo princípio, para a movimentação da matéria, há quase 2.500 anos.

Toda a existência era formada pela ação do agrupamento de átomos. Com base nessa suposição, Demócrito concluiu que a sociedade também deveria ser organizada em uma estrutura semelhante. De fato, atribui-se a Demócrito o seguinte fragmento ( $\left.\mathrm{n}^{\circ} 252\right)$, que exemplifica sua defesa do sistema democrático: "La pobreza en una democracia es preferible al llamado bienestar de manos de los poderosos, en la misma medida en que la libertad lo es a la esclavitud" (DEMÓCRITO DE ABDERA, 2012, p. 308).

Cada cidadão - apesar das limitações à cidadania - deveria manifestar sua vontade de forma plena, como se representasse um átomo desse modelo de Leucipo e Demócrito. Com a superposição das vontades individuais de cada cidadão, formar-se-ia, em tese, a vontade geral da sociedade. É esta, portanto, a essência da democracia: a superposição de opiniões convergentes e divergentes para formação de uma vontade única coletiva determinada pelo princípio majoritário (VASCONCELOS, 2006).

Essa concepção atomística da física transcendeu a mera relação material entre as coisas e o vácuo e assumiu importância fundamental no desenvolvimento da filosofia do homem: "En los tiempos modernos, el modo de ver atomístico se ha hecho más importante en el campo político que en el físico" (HEGEL, 2005, p. 201).

Por essas razões, Demócrito acaba por se enquadrar como um filósofo de transição entre a filosófica pré-socrática (apesar de ser contemporâneo a Sócrates), e a filosofia do homem. Neste campo, atuou de tal modo que sua obra acabou por influenciar a vindoura filosofia política moderna.

Passando à filosofia moderna, mais precisamente à obra de Georg Wilhelm Friedrich Hegel, esse fundamento atomista começa a ser desmontado em favor de uma concepção mais ampla da teoria política, sob influência dos modernos contratualistas (embora com preciosas ressalvas críticas), em especial Thomas Hobbes (2011). 
Cabe breve excursão para esclarecer alguns caracteres de índole atomista presentes em sua obra. Para Thomas Hobbes (2011, p. 126-127): “A essência do Estado consiste nisso e pode ser assim definida: uma pessoa instituída, pelos atos de uma grande multidão, mediante pactos recíprocos uns com os outros". A própria obra artística que ilustra seu livro desde a publicação original, em 1651 - um gigante cujo corpo é formado por diversas figuras humanas - adianta qual era a essência do Estado em sua concepção: uma superposição de vontades individuais para a criação de uma vontade geral.

Toda a doutrina da representação política na democracia moderna tem certo fundamento também nessa mesma doutrina, enquanto as críticas sobre o problema da legitimidade costumam traçar caminho apartado, como se abordará a seguir.

A filosofia política de Hegel se fundamenta parcialmente em remanescentes, à época, ainda pouco explorados da doutrina atomista. A manter como plano de fundo o idealismo alemão que fundara, o filósofo se desfaz da importância físico-naturalista do atomismo para concentrar-se em seu potencial político. Nesse aspecto comenta um de seus principais biógrafos:

[...] se hace patente que esta lógica de la multiplicación de los unos que son cada uno para sí, con su repulsión y atracción mutuas, le interesa más a Hegel como lógica de la relación entre los individuos humanos que como lógica de los indivisibles materiales (átomo significa lo mismo que individuo, advierte Hegel). Es en esta lógica donde Hegel funda su concepción del espíritu como intersubjetividad. ${ }^{2}$ (PLANA, 2005, 200-201).

Para Hegel (1995) o átomo social era o indivíduo, e o turbilhão de agrupamento de átomos era o pacto social. Por meio deste, os indivíduos (unidades atômicas) se relacionariam de forma convergente ou divergente mas esse movimento estava guiado não pela mera força intrínseca dos indivíduos, mas segundo uma outra força que se desenvolve dentro da organização social.

Percebe-se uma sutil evolução da filosofia de Hegel em relação ao atomismo de Abdera. Enquanto, para os antigos, os indivíduos (átomos) eram impulsionados por forças inerentes a si, para Hegel (1995), os indivíduos eram conduzidos tanto por forças

\footnotetext{
2 "É patente que essa lógica da multiplicação das unidades que são cada uma para si, com repulsão e atração mútuas, interessa mais a Hegel como lógica da relação entre os indivíduos humanos que como lógica dos indivisíveis materiais (átomo significa o mesmo que indivíduo, adverte Hegel). É nessa lógica que Hegel fundamenta sua concepção do espírito como intersubjetividade [...]", em tradução livre.
} 


\section{RFD}

endógenas como por forças exógenas. A plenitude do átomo, portanto, fora relativizada a partir dessa concepção. Apenas isso.

Não foi deixada de lado a força endógena do átomo, nem poderia sê-lo, pois, segundo Hegel (1995), essa potência endógena do atomismo (o ser para si), apesar de não ser a última determinante social, não pode ser deixada de lado porque é uma parte lógica da essência da sociedade e das relações intersubjetivas.

Essa concepção do Estado como aglomerado das vontades individuais de cada cidadão a partir da doutrina atomista parece ter escapado à percepção do jovem Karl Marx em sua tese de doutoramento em filosofia intitulada "Diferenças da filosofia da natureza de Demócrito e Epicuro", datada de 1841, na qual afirmou que "El átomo tiene para Demócrito sólo el significado de un stoijeion (elemento), de un sustrato material" (MARX, 1971, p. 46).

Ao revisitar a filosofia atomista, já em 1844, Karl Marx publica sua "Crítica da filosofia do direito de Hegel", na qual finalmente adentra pelos aspectos político-sociais do atomismo, superando seu prévio entendimento meramente físico-naturalístico, cuja superficialidade já houvera sido, anteriormente, criticada por Hegel quanto a seus contemporâneos.

Nessa obra, Karl Marx avança por meio da abertura criada por Hegel e a utiliza para criticar de forma incisiva o fato de este ter-se detido em seu próprio avanço. Em outras palavras, Marx critica Hegel porque este não seguiu além em sua própria trilha, ao ter exposto as forças exógenas de coesão e dispersão dos átomos (indivíduos), mas sem romper em definitivo seus fundamentos, limitando-se a dar nova perspectiva ao atomismo.

A sutil evolução de Hegel em relação aos antigos atomistas foi criticada exatamente por sua sutileza. A excepcionalidade da obra de Marx viria a transformar, em definitivo, a percepção atomística do Estado e da democracia em direção a uma percepção hoje dita "holística".

Enquanto o atomismo apregoa a formação da vontade geral como consequência direta da superposição das vontades individuais, o holismo compreende o resultado final dessa interação como algo independente e (pelo menos relativamente) desvinculado da mera superposição de anseios e percepções individuais. Em termos mais palatáveis, pode-se afirmar, apenas para fins ilustrativos, que, para o holismo, dois mais dois pode não ser igual a quatro. 
A teoria marxista, que explica o Estado como entidade surgida para servir à dominação de uma classe sobre a outra em determinado momento da história social é utilizada para empeçar sua crítica. Intrinsecamente analisada, a sociedade seria um aglomerado de vontades conflitantes e congruentes, mas sua organização no corpo estatal não era resultado de harmonia majoritária entre aquelas diversas unidades conflitantes. Ao contrário, seria uma força a se opor, contraditoriamente, ao próprio corpo social.

A organização da sociedade civil não formula a vontade geral do Estado. Ao contrário, com esta entra em conflito. Há uma fissura entre o estamento privado da sociedade civil e o estamento político do Estado que não pode ser ignorada. Apenas uma parcela do ser "sociedade civil" tem algo em comum com o estamento político, mas essa parcela do estamento privado somente adquire significado político ao sofrer transubstanciação, ao acaba por se desvincular completamente da sociedade civil, e a esta passa a oferecer oposição (MARX, 2010).

Se para o atomismo a organização da sociedade civil é resultante quase matemática da superposição das unidades humanas em seus ideais e convicções distintos, para a percepção holista, sobretudo a partir de Karl Marx, o resultado final pode ser (e efetivamente é) diferente da mera superposição das unidades, dedicando-lhes oposição e repressão.

Segundo Marx (2010), a sociedade civil como estamento privado acaba por separarse de si ao compor o corpo político, o que demonstra a situação dialética contraditória entre a sociedade civil e o Estado. "O ser em comum no qual existe o indivíduo, é a sociedade civil separada do Estado", escreveu Karl Marx (2010, p. 96). Algo impensável à matematicidade atomista.

Ambos os conceitos - atomismo e holismo - permeiam discussões políticas atuais acerca, especial e respectivamente, da busca pela legitimidade da representação democrática e da crítica aos mecanismos de sua verificação por meio do processo formal democrático. Esses temas serão abordados a seguir, ao que será feita referência retroativa ao presente tópico.

\section{AS CONCEPÇÕES DE POVO NA DOUTRINA DE MÜLLER}

A discussão, no presente artigo, passa à análise das concepções de "povo" para a 


\section{RFD}

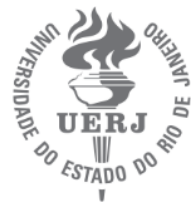

Teoria da Democracia, ciente da necessária ponderação entre a teoria e a prática da realização democrática. Como aponta Hans Kelsen (2000), muitos dos mal-entendidos que acercam a temática têm origem na ausência de confronto entre a teoria e a realidade de como acontece, de fato, o exercício da democracia. Por essa razão, o presente trabalho discorre acerca da concepção de povo na doutrina de Friedrich Müller para, então, contrapor de modo crítico teoria e prática da realidade democrática.

Das concepções atomista e holista acerca da formação social da vontade do Estado, pode-se aprofundar a análise sobre quem seria o povo. Quem é, afinal, o titular do Poder descrito no parágrafo único do art. $1^{\circ}$ da Constituição Federal de 1988? A quem se dirigem as investigações acerca da legitimidade ou da representatividade no exercício do poder? Essa discussão, celebremente suscitada por Friedrich Müller (2010), pode ser observada segundo as concepções atomistas ou holistas do Estado.

Quando a Constituição Federal afirma que todo o poder emana do povo (art. $1^{\circ}$, parágrafo único), que os Deputados são representantes do povo (art. 45), que o Presidente da República deve promover o bem geral do povo (art. 78), ou que o meio ambiente equilibrado é bem de uso comum do povo (art. 225), a quem se refere?

Em sua obra, Friedrich Müller (2010) percebe que o termo “povo”, embora amplamente invocado sem maiores preocupações, padece de indefinição terminológica que exige de quem o invoca o dever de lhe definir. O povo que tem direito ao meio ambiente equilibrado (art. 225) é o mesmo povo representado pelos Deputados (art. 45)? Se sim, porque, então, nem todas as pessoas que compõem o povo do art. 225 podem participar ativamente da escolha dos representantes do art. 45 ?

Com essa questão introdutória, Müller (2010) expõe as diferenças que podem haver entre as concepções de "povo", conforme seja o contexto no qual o termo se insere. Nesse sentido, identificam-se cinco possíveis significados: 1) povo como povo ativo; 2) povo como instância global de atribuição de legitimidade; 3) povo como ícone; 4) povo como destinatário de prestações civilizatórias do Estado; ou 5) povo como conceito de combate.

A primeira acepção, de "povo como povo ativo", aduz à ideia do povo como aquele que exerce ativamente as funções da vida política, como, por exemplo, eleger seus representantes, participar com projetos de lei de iniciativa popular, votar em referendos ou plebiscitos (MÜLLER, 2010). Confunde-se com aqueles detentores da capacidade eleitoral 
ativa, a aptidão a participar ativamente da vida política por meio do alistamento eleitoral (art. $14, \S \S 1^{\circ}$ e $\left.2^{\circ}, C F / 88\right)$.

Em seguida, o "povo como instância global de atribuição de legitimidade". Verificase essa instância quando do relacionamento do povo ativo, eleitor e subscritor de leis (em tese), das normas elaboradas com base hipotética na concordância dos ativos e, regressivamente, da operação e da execução dessas normas por pessoas (autoridades públicas ou particulares) que fundamentam sua atuação na vontade do povo. Diz-se que o fundamento do cumprimento da lei está na "instância global de atribuição de legitimidade", para Müller (2010).

A verificação dessa instância de legitimidade se dá quando da concordância, mesmo tácita, do povo em relação à forma pelo qual as normas vêm sendo executadas. Caso haja discordância, entende Müller (2010), e o povo não lhe atribuísse a legitimidade aqui debatida, haveria revolta popular. A inexistência da rebelião - desde que se permita a resistência - é forma de exteriorizar a aceitação global da legitimidade.

Terceiro, o “povo como ícone”. Trata-se de configuração de uma ordem jurídica deteriorada, na qual a invocação do povo serve unicamente como chamativo. Nessa situação, embora o termo "povo" continue a ser invocado pelo Estado e por suas autoridades, estes o fazem somente como forma de iludir a sociedade (MÜLLER, 2010).

Trata-se de estado excepcional, no qual o poder não deriva diretamente do povo ativo nem possui legitimidade atribuída pelo povo. Nessa circunstância, o termo perde sua materialidade, seu real significado, e torna-se apenas ícone para justificar o exercício do poder - mesmo estando descompassado com qualquer concepção de democracia.

Quando a população não atende às expectativas legitimadoras dos dirigentes do Estado, este pode criar um novo povo, por meio de sua narrativa e imprensa oficiais, de modo a fundamentar sua suposta legitimidade na farsa de uma nova concepção de povo criada unicamente para justificar sua estadia no poder (MÜLLER, 2010).

O "povo criado", o ícone, à imagem e semelhança do Estado criador é observado nas obras de autores dos diversos matizes ideológicos totalitários. As tendências totalitárias desse tipo de manipulação do povo foram bem observadas por John Stuart Mill (2001, p. 97):

A general State education is a mere contrivance for moulding people to be exactly like one another: and as the mould in which it casts them is that which pleases the 
predominant power in the government, whether this be a monarch, a priesthood, an aristocracy, or the majority of the existing generation; in proportion as it is efficient and successful, it establishes a despotism over the mind, leading by natural tendency to one over the body. ${ }^{3}$

Quarto, existe a concepção de "povo como destinatário de prestações civilizatórias do Estado". Refere-se, Müller (2010), à população em geral. Não se restringe aos aptos à participação ativa na política nem àqueles que atribuem legitimidade ao poder. Trata-se da totalidade da população que reside no território do Estado e, portanto, sujeita-se a suas normas e a seus serviços públicos.

A última concepção é a de "povo como conceito de combate". Trata-se da figura de recortar, da sociedade existente, aquele grupo social, étnico, político, econômico (ou por qualquer outra forma de discriminação) que seria o "verdadeiro povo". Esse conceito assemelha-se a uma concretização do povo como ícone. Na medida em que a classe dirigente do Estado seleciona seu ícone legitimador, o povo-combate é recortado e apresenta-se como sua militância (sendo, por isso, muitas vezes “criado", povo-produto).

Essas concepções podem ser relacionadas com as teorias atomistas ou holistas da fundamentação da vontade geral do Estado na exata medida de sua participação no ou oposição ao corpo político existente, como demonstrado.

É natural perceber que a concepção atomista da sociedade possui relação direta com o individualismo metodológico. Isso se dá porque o ser humano individualizado possui interesses e aspirações próprios, por vezes alheios aos daqueles que lhes cercam.

Importa frisar que o individualismo a que se refere neste escólio não pode ser confundido com a ideia pejorativa de individualismo egoísta. O que se objetiva é analisar o ser humano, considerando e respeitando suas liberdades de pensamento, de opinião e de agir; e que esses pensamentos, opiniões e ações têm a ver com sua intimidade, sua individualidade.

A desvalorização do individual perante o coletivo não é fenômeno recente. Hegel (1992) a protagonizou no século XIX, mas desde o período grego clássico é recorrente a concepção coletivista do homem com a cidade. Na modernidade essa premissa se

\footnotetext{
3 “Uma educação geral pelo Estado é mero truque para moldar as pessoas para que sejam exatamente idênticas umas às outras: e como a fôrma na qual as pessoas serão modeladas é aquela que mais agrade ao poder dominante no governo, seja um monarca, um religioso, uma aristocracia ou mesmo a maioria das pessoas existentes; na proporção de sua eficiência e de seu sucesso, estabelece-se um despotismo sobre a mente e, consequentemente, sobre o corpo", em tradução livre.
} 
fundamenta na equivocada concepção do individualismo como supostamente isolador ou egoísta.

Na explanação que se faz necessária, o individualismo, para Jean-Jacques Rousseau (2005), seria a origem da desigualdade entre os homens e o motivo da depravação do "bom selvagem" na sociedade. Fora uma resposta ao individualismo de John Locke (2001), embora com significado diametralmente oposto.

Entretanto, em sua concepção original, o individualismo assemelha-se ao que hoje se intitula comunitarismo: a preocupação do estudo das consequências das relações entre indivíduos (de onde vem sua denominação) em sociedade. Não se concebeu o individualismo como doutrina segregadora dos indivíduos, mas como forma de respeitar e valorizar a individualidade de cada pessoa. Segundo F. A. Hayek (1958, p. 6), o individualismo é na verdade:

\begin{abstract}
a theory of society, an attempt to understand the forces which determine the social life of man, and only in the second instance a set of political maxims derived from this view of society. This fact should by itself be sufficient to refute the silliest of the common misunderstandings: the belief that individualism postulates (or bases its arguments on the assumption of) the existence of isolated or self-contained individuals, instead of starting from men whose whole nature and character is determined by their existence in society. ${ }^{4}$
\end{abstract}

Como se propõe neste trabalho, o individualismo remeterá à análise do ser humano individualmente considerado, com seus desejos e aspirações. Estes podem corresponder aos mesmos desejos e aspirações do restante da sociedade, em sentido comunitário. O fato de o desejo do indivíduo corresponder com o da sociedade não exclui seu caráter individualista. Portanto, o individualismo a que se refere não pode ser confundido com sentimento egoísta, de isolamento e contraposição ao corpo social.

Nesse sentido, cumpre observar que o teor atomista da doutrina de Abdera coadunase com a ideia de individualismo metodológico na medida em que considera o ser humano unidade básica de desejos e vontades tais que se superpõem uns aos outros na formação da vontade geral do Estado.

\footnotetext{
4 "uma teoria da sociedade, uma tentativa de entender as forças que determinam a vida social do homem, e apenas em segunda instância um arcabouço de máximas políticas derivadas desta visão da sociedade. Esse fato por si só deveria ser suficiente para refutar o mais tolo dos desentendimentos comuns: a crença que o individualismo postula a (ou baseia sua argumentação na presunção da) existência de indivíduos autônomos e isolados, no lugar de entender que o caráter e a natureza dos homens estão determinados por sua existência em sociedade", em tradução livre
} 
Como núcleo de desejos e aspirações, ao ser humano se reconhece sua individualidade, sua intimidade. Seres humanos diversos podem ter desejos em comum ou divergentes, que podem variar, ou não, segundo suas condições sociais, econômicas... O núcleo de origem da vontade do Estado é, pois, o indivíduo.

Pelo princípio majoritário, as vontades individuais são postas e contrapostas, sendo que o resultado decorre precisamente desse processo positivo e contrapositivo. O indivíduo, portanto, pelo método democrático, une-se a outros de modo que a vontade da maioria prevalece sobre a vontade da minoria.

Segundo perspectiva holista, os seres humanos até podem ter certo grau de autonomia ou individualidade em seus desejos privados. Mas essa característica está limitada pelo meio social e, na medida em que o corpo social cresce (da família ao Estado geral), as diferenças vão se agigantando, somando-se de tal modo que a vontade do corpo social resultante opõe-se às vontades individuais (MARX, 2010).

O povo, sob a óptica holista, aproxima-se da concepção de "povo como ícone" ou "povo como combate" na medida em que, ainda que invocados pelo Estado como fundamento de sua legitimidade, este em verdade prestaria oposição à população civil em geral.

Segundo percepção atomista, as vontades individuais reunir-se-iam para decidir pela vontade geral, pelo critério majoritário. Destarte, a decisão política resultante, presume-se, é compatível com os anseios da maioria do povo atuante. Por essa razão, parlamento e a legislação são (ou eram) encarados como reflexos - pelo menos a princípio legítimos - do exercício da soberania popular, como se demonstra a seguir (ZARKA, 2016).

\section{HISTÓRIA DA LUTA PELA DEMOCRACIA E O SURGIMENTO DAS MODERNAS DEMOCRACIAS INDIRETAS}

A luta pela democracia, em oposição às formas de governo autocráticas absolutistas, nos Séculos XVII e XIX consistiu na luta por maior representação popular (à época, representação da burguesia) como fator de influência na formação da vontade do Estado, defende Hans Kelsen (2000).

$\mathrm{Na}$ verdade, a luta pela representatividade data de bem antes. Isso porque, já na Magna Carta Libertatum, assinada em 1215 pelo Rei João sem Terra, foram instituídos 
diversos direitos e garantias aos cidadãos, inclusive o direito à representação. Ao longo de seus 63 artigos, constam normas que asseguram o direito ao habeas corpus, as liberdades religiosas e, quanto à tributação, tornou necessária a concordância do povo por meio do conselho dos comuns: "no taxation without representation" (MARTINEZ; CABALLERO, 2013).

Nos regimes democráticos, pressupõe-se a participação popular na tomada das decisões políticas. Essa manifestação pode se dar direta ou indiretamente, a depender da existência (nesta) ou da inexistência (naquela) de um intermediário que, teoricamente, atue como portador da vontade do povo, conforme explanação a seguir.

Na filosofia do homem, na Grécia antiga, a ideia de liberdade estava de certo modo relacionada com a participação do homem na vida política. Livre seria aquele que fosse útil à sociedade. Havia, pelo menos formalmente, cumplicidade entre o cidadão e a cidade. Aqueles que participavam da vida política gozavam de uma aparência de civilidade superior aos demais. A participação política - a civilidade - sobretudo em Atenas, continuou a ser considerada, na democracia, uma tradição de nobreza mesmo após o declínio da aristocracia (HELD, 2006).

O postulado da participação direta assegurava que todos os "cidadãos" estivessem sob a égide da isagoria: o igual direito à voz na assembleia do povo. Embora a qualidade de cidadão na Grécia antiga não fosse tão universal quanto atualmente, fontes históricas apontam que a quantidade de cidadãos atenienses estava entre 35.000 (trinta e cinco mil) e 45.000 (quarenta e cinco mil) indivíduos, sendo de 6.000 (seis mil) o quorum para dar início aos debates (HELD, 2006).

Dentre as restrições à cidadania, apenas os homens atenienses de mais de 20 (vinte) anos poderiam exercer a vida pública. Escravos, estrangeiros e mulheres estavam excluídos da condição de cidadãos e da possibilidade de participação na política. Apenas excepcionalmente, mediante aprovação da assembleia, a cidadania poderia ser estendida a pessoas que não cumprissem seus requisitos (HELD, 2006).

A atual formação geopolítica do Estado-nação dificulta bastante a participação direta, pelo menos como regra geral. Há, todavia, quem considere ser possível a adoção da democracia direta - a despeito da dimensão geográfica ou populacional - desde que seja instituída juntamente com o reconhecimento do direito de secessão (SOTO, 2002). Em todo caso, com a crescente complexidade das sociedades modernas, tornou-se necessário o 


\section{RFD}

desenvolvimento de um método de unificação das vontades unitárias, de modo a permitir a participação política, indiretamente.

À época da Convenção da Filadélfia, em 1787, já se discutia acerca das dificuldades de implementação de um sistema democrático direto à debutante federação norteamericana (MADISON, 1984). Anos antes, Montesquieu (1996) atentara para a onerosa operação de uma democracia direta em um Estado de grande população ou considerável extensão territorial por ser bastante dificultoso reunir todo o povo, seja ele numeroso ou disposto em vasto território, regularmente, para tratar de deliberações públicas. Com efeito, a democracia direta só poderia funcionar em nações pequenas.

À vista da vertiginosa complexidade das sociedades modernas, sobretudo após a Revolução Industrial, inconcebível se tornou o mecanismo de intervenção direta do povo sobre o poder político como regra geral. Fora necessário condensar a vontade de um conjunto de cidadãos na de alguns poucos representantes para viabilizar o exercício democrático em um vasto território.

A mediação de um interlocutor faz recair sobre a democracia indireta a acusação de que não seria efetivamente o povo a governar, mas uma classe política alheia aos reais interesses dos eleitores (SARTORI, 2007). Essa posição do representante faz com que muito se questione se essa atividade pública não poderia ser apropriada por uma elite que se utilize do sistema político apenas para permanecer no poder (SANTOS, 1962).

\section{PARLAMENTO E LEGISLAÇÃO COMO INSTITUIÇÕES CONSOLODADORAS DA VONTADE DO POVO - E CRÍTICAS A ESSA CONCEPÇÃO}

Nas democracias indiretas - bem como nas semidiretas - o Parlamento é a instituição que congrega os representantes do povo. No Brasil, o alhures mencionado art. 45 CF/88 estabelece que, a nível federal, a representação popular é exercida pelos Deputados Federais.

A instituição Parlamento, embora padeça atualmente de pouco reconhecimento popular, foi seio de importantes conquistas democráticas, lembra Kelsen (2000). Dentre elas, menciona a garantia das liberdades políticas e da igualdade formal, com o fim dos direitos estamentais.

A ideia por trás do Parlamento é que este funcione como o ambiente no qual os 
representantes do povo se reúnam, discutam e, por voto majoritário, enfim aprovem normas que expressem, em linguagem jurídica, a vontade do povo que os elegeu. Nesse sentido, temos a lei, elaborada pelo Parlamento no exercício da função legislativa, como fruto do processo democrático - e, portanto, como consolidação da vontade geral do povo exercida por meio de seus mandatários.

Trata-se de ideal no qual o povo deposita confiança nos seus representantes, e estes, conscientes dos anseios daqueles que Ihes confiaram o mandato, agem em seu nome. Esse compromisso da vontade do Estado com a mais numerosa vontade popular confere à democracia a identidade da vontade individual com a geral. Claro, hipoteticamente.

Isso, por óbvio, nem sempre acontece. A teoria da confiança entre o delegado e o que delega nem sempre se verifica na realidade. Muitas vezes, a vontade que expressa o mandatário, ao chegar ao poder, em nada condiz com a vontade daquele que o enviou ao parlamento, e, nesses casos, pode-se verificar uma das fragilidades da democracia indireta (CANOTILHO, 2000).

Essa concepção de que o representante do povo deve servir como porta-voz da vontade individual de seus eleitores perante o Parlamento, embora difundida no imaginário popular contemporâneo, não é inteiramente verdade. Eis certa ressalva quanto à representatividade do povo. É que sua função se aproxima muito mais de ser depositário da confiança de seus eleitores, que de apenas agir como seu porta-voz, como se fora mera caixa de ressonância. Em discurso proferido aos eleitores de Bristol, no Reino Unido, em 1774, Edmund Burke (1999, p. 10-11) demonstrou que a função do representante eleito pelo povo é não apenas ser porta-voz das vontades individuais:

Certainly, Gentlemen, it ought to be the happiness and glory of a Representative, to live in the strictest union, the closest correspondence, and the most unreserved communication with his constituents. Their wishes ought to have great weight with him; their opinion high respect; their business unremitted attention. It is his duty to sacrifice his repose, his pleasures, his satisfactions, to theirs; and, above all, ever and in all cases, to prefer their interest to his own. But, his unbiased opinion, his mature judgment, his enlightened conscience, he ought not to sacrifice to you; to any man, or to any sett of men living. These he does nor derive from your pleasure; no, nor from the Law and the Constitution. They are a trust from Providence, for the abuse of which he is deeply answerable. Your Representative owes you, not his industry only, but his judgment; and he betrays, instead of serving you, if he sacrifices it to your opinion. ${ }^{5}$ (BURKE, 1999, p. 10-

\footnotetext{
5 “Certamente, cavalheiros, que deveria ser a felicidade e a glória de um representante, viver na mais estrita união, na mais próxima correspondência, e na comunicação mais sem reservas com os seus eleitores. Seus desejos devem ter grande peso com ele; sua opinião, elevado respeito; seu negócio, a mais confiável atenção.
} 
Está configurada a chamada "crise de legitimidade do parlamento", analisada sob a óptica de diversos autores, dentre os quais Luhmann (1980), Hayek (1985), Habermas (1997), Kelsen (2000), Otero (2015) e Zarka (2016).

O questionamento se o Parlamento realmente representa legitimamente a vontade popular, lembra Kelsen (2000), somente veio a tona após a vitória do parlamento sobre as organizações políticas então vigentes. Enquanto perdurava a monarquia absolutista, a atuação do parlamento era tida como o ápice - até então - que a sociedade poderia atingir em termos de representação popular. Somente após a derrota do "inimigo maior" - os regimes absolutistas - o parlamento passou a ser objeto desses questionamentos:

O caráter fictício da ideia de representação não exigiu naturalmente atenção enquanto durou a luta da democracia contra a aristocracia e enquanto o próprio parlamentarismo não conseguiu suplantar completamente o monarca e as ordens. Sob a monarquia constitucional, durante o tempo em que o parlamento eleito pelo povo teve de ser considerado o máximo do que, politicamente, era possível arrancar do monarca antes absoluto, não tinha sentido criticar a forma política perguntando se o parlamento representava realmente a vontade do povo. (KELSEN, 2000, p. 49)

A descrença na lei como formalizadora da vontade popular fez com que a superior hierarquia da Constituição fosse buscada como alternativa à necessidade de um suporte normativo delimitador e legitimador da vontade estatal. Sobretudo após os regimes totalitários de meados do Século XX, a ideia de superioridade da lei tem estado bastante relativizada em favor, atualmente, da busca pela constitucionalização do Direito (BINENBOJM, 2008).

A questão da legitimidade democrática, e mais especificamente da legitimidade do parlamento como representante do povo, também é objeto de especial atenção na obra de Carl Schmitt (2004). O autor, contudo, não expande suas críticas a todas as formas de democracia, apenas à chamada "democracia liberal", que entende ser a "falsa democracia".

É seu dever sacrificar seu repouso, seus prazeres, suas satisfações, para as deles; e, acima de tudo, sempre e em todos os casos, preferir o interesse deles ao seu próprio. Mas, sua opinião imparcial, seu julgamento maduro, sua consciência iluminada, ele não deve sacrificar a você; a qualquer homem, ou a qualquer grupo de homens vivos. Estes que ele tiver não derivam de seu prazer; não, nem da lei e da Constituição. Eles são um legado da Providência, para o qual ele será profundamente responsável. Seu Representante lhe deve, não só a sua indústria, mas seu julgamento; e ele trai, em vez de servi-lo, se ele os sacrificar à sua opinião", em tradução livre. 


\section{RFD}

O que se denomina "democracia liberal" é a forma de organização calcada na liberdade de opinião e igualdade formal na representação, tendo o parlamento papel fundamental no exercício mediado do poder político. Para Schmitt (2004), essa falsa democracia serve apenas de instrumento de dominação da classe burguesa (ZARKA, 2016), e deveria ser substituída pela verdadeira democracia, baseada em plebiscitos para direta participação popular.

As críticas que se fazem ao parlamento e à doutrina liberal da concepção de democracia tramitam no sentido de questionar sua legitimidade perante o verdadeiro anseio da população. Esses questionamentos, embora bastante pertinentes, podem por vezes dar a falsa impressão de que a vontade popular (do povo ativo) é, necessariamente, a expressão máxima da sociedade.

Nesse sentido, nos últimos anos, diversos ensaios de Teoria do Direito e de Ciência Política têm sido elaborados no sentido de buscar maior aproximação da realização da vontade do povo na democracia, o que é desejável e deve sim ser pretendido. Todavia, carecem questionamentos acerca dos limites desse poder decisório do povo, que não pode nem ser ilimitado nem ser tomado como critério axiológico.

\section{A AUTORIDADE DA MAIORIA: DEMOCRACIA COMO PRINCÍPIO AXIOLÓGICO}

Sob qualquer corrente filosófica que se aproxime o leitor - atomismo ou holismo ambas devem ser criticamente analisadas quanto aos limites do poder decisório da maioria. Inicialmente, a discussão já se justifica, sob o prisma atomista, quanto à possibilidade de violação dos direitos da minoria derrotada, ou, sob prisma holista, na possibilidade de ambas - maioria e minoria - virem a sofrer violações decorrentes da oposição que a vontade geral lhes imprime.

$\mathrm{O}$ aspecto mais fundamental da democracia, que a distingue de outras formas de organização do exercício do poder, é a ideia de sua titularidade provir do povo e ser por si exercida, segundo o princípio majoritário. Mesmo nas diversas formas de democracia existentes, desde a democracia direta ou indireta, liberal ou social, o que as difere é o modo de se auferir a existência do entendimento majoritário, mas este sempre se faz presente.

A forma de verificação da ocorrência do consenso razoável (existência de posicionamento majoritário) pode se dar de diversos modos. Consulta direta à população, 
com plebiscitos, ou atuação de representantes eleitos são exemplos de métodos utilizados para expressar a opinião popular - e assim verificar qual é a majoritária.

Sob análise superficial, pode-se vir a crer que o princípio da maioria atende à busca pelo "menor prejuízo". Se determinada decisão política pode ser tomada segundo duas ou mais possibilidades, seguir aquela que atende à maior parcela da população parece minimizar os riscos de sua tomada, pelo menos quanto à eventual insatisfação popular.

Não raro, todavia, essa preferência à maioria leva a conclusões inadequadas. Isso porque o respeito ao método do princípio majoritário concede à decisão política embasamento quantitativo de que aquela decisão está de acordo com o que pensa a maioria do povo. Mas do princípio majoritário não se pode extrair nenhuma conclusão de ordem qualitativa, material.

O método democrático precisa ser reconhecido como método que é. Não se pode utilizar de si para encontrar supostos valores morais qualitativos. É dizer a neutralidade axiológica do conceito de democracia: do princípio majoritário pode-se concluir que " $\mathrm{x}$ " ou "y" é desejado pela maioria; mas não se pode concluir que " $\mathrm{x}$ " ou "y", por ser desejado pela maioria, é naturalmente melhor que suas alternativas (VASCONCELOS; ARAUJO, 2017).

É o que Tocqueville denominou "império moral da maioria": "O império moral da maioria se baseia, em parte, na ideia de que há mais luzes e sabedoria em muitos homens reunidos do que num só, mais no número de legisladores do que na escolha" (TOCQUEVILLE, 2005, p. 290).

Mas qual a origem desse mito do valor axiológico de uma decisão majoritária? Alguns autores a identificam no próprio mito do parlamento e da superioridade da lei, embora sob perspectiva diversa da demonstrada alhures.

Anteriormente, mencionou-se a ascensão do parlamento a instituição orgânica central dos regimes democráticos, na exata medida em que, teoricamente, serve a congregar os representantes da sociedade, permitir o debate de ideias e a tomada de decisões em obediência ao princípio majoritário. Contudo, desse protagonismo do parlamento surgem questionamentos. Primeiro quanto a sua real legitimidade para representar o povo. Segundo, mais aprofundado, qual seria o limite de atuação do parlamento, mesmo se ele fosse realmente legítimo.

O ponto central da discussão é: algumas decisões tomadas no parlamento - e 


\section{RFD}

convertidas em lei - são criticáveis porque o parlamento não corresponde à vontade da maioria ou porque, ainda que a maioria ratificasse a decisão, ela poderia ser naturalmente ruim?

A ideia de superioridade da lei - ato resultante da decisão do parlamento - implica nessas problemáticas. Será que uma lei ruim o é porque não corresponde à vontade do povo? Ou uma lei ruim o é porque seu conteúdo é essencialmente ruim? A resposta a essa questão passa pelos seguintes aspectos: o procedimento como legitimação e os limites à autoridade da maioria.

Sem dúvidas é questão importantíssima da análise democrática verificar se - e assegurar que - o parlamento condiz com a adequada representação que lhe fora conferida. Todavia, surge a segunda questão, que pretende ser desenvolvida neste tópico: se o parlamento fosse completamente legítimo e decidisse sempre em total concordância com a vontade da maioria, estaria ele autorizado a tomar qualquer decisão? E essa decisão, qualquer que fosse, estaria protegida de críticas somente por ser reflexo legítimo da vontade da maioria?

Já no Século XIX, Alexis de Tocqueville (2005) suscitava a possibilidade de um regime democrático desvelar em verdadeira "tirania da maioria", situação na qual toda e qualquer decisão política pudesse ser justificada com base no suposto anseio popular. Essa hipótese afasta a democracia de seu sentido histórico - limitador do poder - e a aproxima demasiado dos regimes que tentou suplantar, notadamente o absolutismo.

Afirma Tocqueville que "fora da maioria, não há nada que resista nas democracias" (2005, p. 289). Essa percepção se justifica porque, pela própria definição do método do sistema democrático, a minoria sempre sairá derrotada das disputas.

A concepção moderna da democracia, como expõe Kelsen (2000, p. 67), pressupõe o respeito aos direitos das minorias como essencial ao resguardo do ordenamento e da própria sociedade: “a existência da maioria pressupõe, por definição, a existência de uma minoria e, por consequência, o direito da maioria pressupõe o direito à existência de uma minoria".

Destarte, eis a principal restrição ao poder decisório da maioria: ele não pode ultrapassar o mínimo existencial dos direitos fundamentais das minorias contrapostas. Essa limitação, todavia, é bastante fragilizada em virtude da possibilidade de restrições 
desmensuradas dos direitos e liberdades fundamentais das minorias por meio do sequestro, pela maioria, das estruturas do Poder Legislativo e do Poder Constituinte.

A ideia de direitos humanos, em ambiente de Direito Internacional, fortalece o núcleo fundamental dos direitos das minorias. Isso porque o conteúdo de tais direitos não se sujeita às mesmas instabilidades legislativas que as garantias positivadas nas Constituições e leis nacionais.

Quando o Estado ou uma parcela da sociedade (mesmo que esta seja majoritária) precisa reconhecer os direitos individuais, o Estado e a sociedade se sub-rogam no poder de decidir quais regras deveriam ser adotadas para tanto. Desse modo, aquelas pessoas interessadas em praticar essas condutas perdem o poder sobre as próprias vidas diante de um grupo dominante que se intitula detentor de uma razão superior à dos interessados:

[...] toda vez que a regra da maioria desnecessariamente substituir a escolha individual, a democracia estará em conflito com a liberdade individual. Esse é o tipo de democracia que deve ser mantido ao mínimo, a fim de se preservar um máximo de democracia compatível com a liberdade individual. (LEONI, 2010, p. 136).

Parece bastante democrático, por exemplo, o fato de que, após uma consulta direta à população ou depois de deliberação de seus representantes, seja terminantemente proibido qualquer relacionamento amoroso entre pessoas do mesmo sexo: "a omnipotência da lei, assentado no primado da vontade maioritária da colectividade, justifica uma legitimidade para tudo fazer em nome da democracia." (OTERO, 2015, p. 170).

Não parece, entretanto, ser justa a decisão democrática mencionada. Referido exemplo salienta que o adjetivo "democrático" não pode ser entendido como algo necessária e indubitavelmente bom. A maioria não pode ser utilizada como critério de moralidade:

[...] a maioria ou mesmo a unanimidade de um parlamento, tal como a vontade da maioria dos membros da sociedade expressa por referendo, nunca pode tornar legítimo aquilo que por natureza é ilegítimo, tal como não pode transformar em certo o que é em si mesmo errado. (OTERO, 2015, p. 171)

Efetivamente, elementos estruturais do Estado, como constitucionalismo, direitos fundamentais, separação dos poderes e, mais especificamente, a eleição proporcional para o Legislativo foram todos mecanismos desenvolvidos também com caráter contramajoritário, 


\section{RFD}

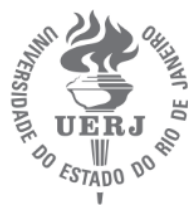

para proteger as minorias do abuso que poderia ser cometido por meio de uma apropriação do mecanismo democrático por uma maioria tirana.

Por fim, embora a internacionalização dos direitos humanos - e a exigência de seu respeito pelos Estados nacionais - possa servir de limite à expansão exacerbada da autoridade da maioria, é necessário cultivar, na sociedade, sentimento cultural antitotalitário, de respeito às liberdades e garantias individuais, e restrição social do poder decisório da maioria.

A ampliação de um sistema de decisões particulares, até de certo modo alheio à democracia majoritária, por meio da liberdade individual, permite uma fertilização interessante do debate, ao suscitar uma união complementar das condições ético-políticas para um amplo reconhecimento dos sujeitos políticos e sociais condizentes com a existência de uma sociedade pluralista (ALBUQUERQUE; ARAUJO, 2017).

Com efeito, uma releitura do objeto da deliberação democrática e uma imediata reversão da tendência publicista do Direito se fazem necessárias para assegurar a cada pessoa na sociedade um núcleo privado de proteção perante eventuais abusos do poder decisório da maioria, que não pode, por si só, ser considerado legítimo.

\section{CONCLUSÕES}

Neste escrito, demonstrou-se o surgimento da democracia na Grécia antiga, assim entendida, para fins metodológicos, como o regime limitador do exercício do poder político baseado na anuência direta ou indireta do povo na vontade geral do Estado. Embora a ideia de democracia tenha o sentido esvaziado atualmente, essa conceituação se faz necessária para o encaminhamento do estudo.

Com fundamento histórico-filosófico na democracia grega, demonstrou-se a dialética existente entre as diversas concepções sobre o instituto, especialmente quanto ao embate filosófico entre as teorias atomista e holista do corpo social. Em seguida, passou à análise do conceito de "povo" para fins de averiguação da legitimidade das decisões democráticas.

Passou a examinar o funcionamento institucional da democracia direta para explanar seu desaparecimento na modernidade em prol dos mecanismos de representação da 


\section{RFD}

democracia indireta. O surgimento da democracia indireta acarretou problemas estruturais relativos à necessidade de representação.

As feições tradicionais que buscam assegurar limites formais e materiais ao exercício do poder político pelo grupo majoritário, em um regime democrático, não tiveram êxito. Por fim, conclui-se que, ante a insuficiência dos mecanismos formais de garantia dos limites à autoridade da maioria, faz necessária a revisão do objeto das decisões democráticas, para assegurar aos indivíduos e à comunidade o poder decisório individual acerca de questões eminentemente privadas, protegendo-as de eventuais abusos praticados pela maioria.

\section{BIBLIOGRAFIA}

ALBUQUERQUE, Newton de Menezes; ARAUJO, Guilherme Dourado Aragão Sá. A democracia contemporânea e a crítica aos limites entre público e privado: por uma nova teoria da cidadania. Revista Brasileira de Direito, Passo Fundo, vol. 13, n. 3, p. 607-624, set./dez., 2017.

BINENBOJM, Gustavo. Uma teoria do direito administrativo: direitos fundamentais, democracia e constitucionalização. 2. ed. Rio de Janeiro: Renovar, 2008.

BURKE, Edmund. Speech to the electors of Bristol. In: CANAVAN, Francis (ed.). Selected works of Edmund Burke. Indianapolis: Liberty Fund, 1999. v. 4.

CANOTILHO, J. J. Gomes. Direito Constitucional e Teoria da Constituição. 7. ed. 11. reimp. Coimbra: Almedina, 2000.

CHAUÍ, Marilena. Introdução à História da Filosofia. 2. ed. São Paulo: Companhia das Letras, 2010. 1. v.

DEMÓCRITO DE ABDERA. Primeros atomistas: fragmentos de Demócrito. In: PAJARES, Alberto Barnabé (org.). Fragmentos pré-socráticos: de Tales a Demócrito. 2. reimp. Madrid: Alianza Editorial, 2012.

GOYARD-FABRE, Simone. O que é democracia? A genealogia filosófica de uma grande aventura humana. São Paulo: Martins Fontes, 2003.

HABERMAS, Jürgen. Direito e Democracia: entre facticidade e validade. 2. v. Tradução de Flávio Beno Siebeneichler. Rio de Janeiro: Tempo Brasileiro, 1997.

HAYEK, F. A. Direito, legislação e liberdade. 3. v. Tradução de Henry Maksoud. Rio de Janeiro: Visão, 1985.

. Individualism and economic order. Chicago: University of Chicago Press, 1958. 
HEGEL, G. W. F. (Georg Wilhelm Friedrich). Enciclopedia de las ciencias filosóficas. 2. reimp. Madrid: Alianza Editorial, 2005.

. Fenomenologia do espírito. Petrópolis: Vozes, 1992. 1. v.

- Lecciones sobre la historia de la filosofía. 5. reimp. Traducción de Wenceslau Roces. Madrid: Fondo de Cultura Económica, 1995. 1. v.

HELD, David. Models of democracy. 3. ed. Cambridge: Polity Press, 2006.

HOBBES, Thomas. Leviatã: matéria, forma e poder de um Estado eclesiástico e civil.7. reimp. São Paulo, Martin Claret, 2011.

KELSEN, Hans. A Democracia. 2. ed. São Paulo: Martins Fontes, 2000.

LEONI, Bruno. A liberdade e a lei: os limites entre a representação e o poder. 2. ed. São Paulo: IMB, 2010.

LOCKE, John. Segundo tratado sobre o governo civil: ensaio sobre a origem, os limites e os fins do verdadeiro governo civil. 3. ed. Petrópolis: Vozes, 2001.

LUHMANN, Niklas. Legitimação pelo procedimento. Tradução de Maria da Conceição Côrte-Real. Brasília: Editora da Universidade de Brasília, 1980.

MADISON, James. Repúblicas representativas e democracias diretas. In: HAMILTON, Alexander; MADISON, James; JAY, John. O federalista. Brasília, Universidade de Brasília, 1984.

MARTINEZ, Jean-Claude; CABALLERO, Norma. 1215-2015: 800 ans après la Magna Carta... une charte europeenne des guaranties du contribuable. In: ALMEIDA, Daniel Freire e; GOMES, Fábio Luiz; CATARINO, João Ricardo (orgs.). Garantias dos contribuintes no sistema tributário. São Paulo: Saraiva, 2013.

MARX, Karl. Crítica da Filosofia do Direito de Hegel. 2. ed. São Paulo: Boitempo, 2010.

. Diferencia de la Filosofía de la Naturaleza en Demócrito y en Epicuro. Madrid: Ediciones Castillas, 1971.

MILL, John Stuart. On liberty. Kitchener: Batoche Books, 2001.

MONTESQUIEU, Charles de Secondat, Barão de. O espírito das leis. São Paulo: Martins Fontes, 1996.

MÜLLER, Friedrich. Quem é o povo? A questão fundamental da democracia. 5. ed. São Paulo: Revista dos Tribunais, 2010. 


\section{RFD}

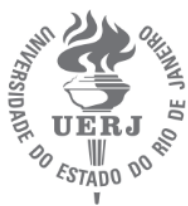

OTERO, Paulo. A democracia totalitária: do Estado totalitário à sociedade totalitária. A influência do totalitarismo na democracia do Século XXI. 2. reimp. Cascais: Principia, 2015.

PLANA, Ramón Valls. Nota del traductor. In: HEGEL, G. W. F. (Georg Wilhelm Friedrich). Enciclopedia de las ciencias filosóficas. 2. reimp. Madrid: Alianza Editorial, 2005. p. 200201.

ROUSSEAU, Jean-Jacques. Discurso sobre a origem e os fundamentos da desigualdade entre os homens. São Paulo: Martin Claret, 2005.

SANTOS, Mário Ferreira dos. O problema social. São Paulo: Logos, 1962.

SARTORI, Giovanni. ¿Qué es la democracia? Madrid: Taurus, 2007.

SCHMITT, Carl. Legality and legitimacy. Translated by Jeffrey Seitzer. Durham: Duke University Press, 2004.

SOTO, Jesús Huerta de. Nuevos estudios de Economía Política. Madrid: Unión Editorial, 2002.

TOCQUEVILLE, Alexis de. A democracia na América: leis e costumes. 2. ed. São Paulo: Martins Fontes, 2005.

VASCONCELOS, Arnaldo. Direito, humanismo e Democracia. 2. ed. São Paulo: Malheiros, 2006.

VASCONCELOS, Arnaldo; ARAUJO, Guilherme Dourado Aragão Sá. Reflexões sobre a estrutura lógico-formal da norma jurídica ante a sanção premial. Pensar, Fortaleza, v. 22, n. 1, p. 59-88, jan./abr., 2017.

ZARKA, Yves Charles. Métamorphoses du monstre politique et autres essais sur la Démocratie. Paris: Presses Universitaires de France, 2016. 